\title{
Clonality testing of lymphoproliferative disorders in a large cohort of primary and consultant biopsies
}

\author{
Michaela Svachova ${ }^{\mathrm{a}}$, Martin Tichy ${ }^{\mathrm{a}}$, Patrik Flodra , Jana Steigerova ${ }^{\mathrm{a}, \mathrm{b}}$, Zdenek Kolar ${ }^{\mathrm{a}, \mathrm{b}}$, Jan Bouchala, ${ }^{\mathrm{a}}$
}

Background. Lymphoproliferative disease often presents the clinician and pathologist with a diagnostic dilemma, particularly in the early course of the disease.

Methods. We used modified BIOMED-2 protocols to detect monoclonal expansions of immunoglobulin heavy chain $(\mathrm{IgH})$ and T-cell receptor (TCR) genes in 957 formalin-fixed paraffin-embedded samples from 717 patients. To eliminate false-positive results, heteroduplex analysis was used after PCR reactions. The impact of different fixatives on DNA quality and performance of PCR was assessed.

Results. In the class of B lymphomas we detected clonal lgH rearrangement in nearly $80 \%$ of cases and in the class of T lymphomas in $64 \%$ of cases. Performance of the assays was $94.7 \%$ and $92.5 \%$ for IgH and TCR clonality, respectively. Clonality rates in various $\mathrm{B}$ and $\mathrm{T}$ lymphomas were in concordance with previous studies. We also present 10 difficult cases where PCR analysis of $\mathrm{IgH}$ and TCR gene rearrangements significantly contributed to a decision on the correct diagnosis.

Conclusion. These results confirm that the PCR-based analysis is suitable as a routine method and is helpful in establishing a diagnosis in morphologically unclear cases.

Key words: clonality; IgH and TCR gene rearrangement; lymphoid proliferation; polymerase chain reaction; BIOMED-2

Received: July 14, 2016; Accepted with revision: February 24, 2017; Available online: March 14, 2017

https://doi.org/10.5507/bp.2017.006

${ }^{a}$ Department of Clinical and Molecular Pathology, Faculty of Medicine and Dentistry, Palacky University Olomouc and University Hospital Olomouc, Czech Republic

bInstitute of Molecular and Translation Medicine, Faculty of Medicine and Dentistry, Palacky University Olomouc, Czech Republic Corresponding author: Jan Bouchal, e-mail:jan.bouchal@gmail.com

\section{INTRODUCTION}

Malignant lymphomas are neoplasms that arise from lymphoid cells of either B-cell or T-cell lineage ${ }^{1,2}$ and are generally diagnosed via histomorphology and immunohistochemistry. In 5-15\% of cases of lymphoproliferative diseases the differential diagnosis between reactive lesions and malignant lymphomas is inconclusive, requiring complementary methods ${ }^{2}$. In these cases, molecular assessment of clonal immunoglobulin heavy chain (IgH) and T-cell receptor (TCR) gene rearrangement by PCR is an important diagnostic tool ${ }^{3}$. PCR-based tests are rapid, exquisitely sensitive and therefore applicable to very small quantities of DNA and can also be performed on formalin-fixed, paraffin-embedded (FFPE) tissues. However, the sensitivity and reproducibility of the PCR method can often be negatively influenced by a poor quality of extracted DNA $\left(\right.$ ref $\left.^{46}\right)$. Formaldehyde can cause a number of DNA changes and damage such as breaks, base substitutions, base losses, base modifications, and cross-linking between nucleic acid strands ${ }^{7,8}$. Other factors that affect the results and validity of the IgH-PCR assay are ineffective primer binding owing to imprecise annealing of the primers to all potential $\mathrm{V}$ and $\mathbf{J}$ segments (see below in text) and somatic hypermutation (SHM) in the Ig genes of the germinal center (GC) and post-germinal center (post-GC) derived lymphomas ${ }^{3,9,10}$.
To generate the diversity and the tremendous number of B-cell and T-cell antigen receptors, the immunoglobulin (Ig) and TCR genes are assembled by the somatic recombination of variable $(\mathrm{V})$, diversity $(\mathrm{D})$, and joining $(\mathrm{J})$ gene segments by a mechanism known as $\mathrm{V}(\mathrm{D}) \mathrm{J}$ recombination $^{11-15} . \mathrm{V}(\mathrm{D}) \mathrm{J}$ rearrangement is a site-specific recombination process that occurs only in developing lymphocytes and only between Ig and TCR gene segments flanked by highly conserved recombination signal sequences ${ }^{16-18}$. Terminal deoxynucleotidyltransferase (TdT) is a DNA polymerase that contributes to another diversification of antigen receptors by random deleting or adding of nucleotides, called N-regions, to gene segment junctions during $\mathrm{V}(\mathrm{D}) \mathrm{J}$ recombination in a template-independent manner ${ }^{19,20}$. This process occurs early in lymphoid ontogeny in both B and T cells, essentially in tandem with the rearrangement process. Other mechanisms contributing to this variability include somatic hypermutation that is restricted to the later GC phase of B cell development ${ }^{10,20}$.

The analysis of Ig and TCR antigen receptor genes and their rearrangements is central to the assessment of the clonality of lymphoproliferative disorders and can distinguish a reactive (polyclonal) proliferation from a neoplastic (monoclonal) proliferation ${ }^{21-23}$. The benign reactive lymphoid proliferation is heterogenous with many different clones which have different rearrangements of their $\mathrm{IgH}$ and TCR genes and by PCR amplified fragments 
range in a size depending on the number of $\mathrm{N}$-sequences added by TdT $\left(\right.$ ref. $^{24}$ ). This normal distribution due to $\mathrm{N}$-region insertion and to the exonuclease activity of the recombinase system is seen as a smear on polyacrylamide gel electrophoresis (PAGE). By contrast, the neoplastic lymphoproliferations with a monoclonal rearrangement produce PCR products of homogenous size and after electrophoresis, one or two distinct bands are found depending on whether one or both alleles were rearranged ${ }^{4,6,23}$. The main objective of our study was to determine the extent to which this analysis might contribute to a correct diagnosis in morphologically unclear cases of lymphoproliferative disorders.

\section{MATERIALS AND METHODS}

\section{Patients and specimens studied}

All the clinical samples analysed were obtained from formalin-fixed, paraffin-embedded tissue biopsies selected from the files of the Department of Clinical and Molecular Pathology at the University Hospital in Olomouc and from biopsy material delivered to our department for the "second reading" from other hospitals. This report summarizes outcomes of the PCR analysis of the 957 samples (from 717 patients). 393 were lymph nodes; 218 skin; 40 bone marrow; 29 mediastinum; 28 stomach; 21 intestine; 20 parotid glands; 20 mouth cavity; 20 pharynx; and also several samples of nasopharynx, tonsils, spleen, thyroid glands, conjunctiva, orbit, eyelid, mamma, prostate, mesenterium, duodenum, caecum, lung, liver, rectum. The first surgical and pathologist's diagnosis were unknown to the person performing the PCR analysis at the time of sample testing.

\section{DNA isolation, polymerase chain reaction and heteroduplex analysis}

Total genomic DNA from FFPE biopsy samples was extracted by the Puregene ${ }^{\circledR}$ DNA isolation Kit (Gentra Systems, Minneapolis, USA) according to our published protocol and quantified on POWER Wave XS (BIOTEK®Instruments, INC., USA) (ref. ${ }^{25}$ ). To ensure amplifiable DNA from paraffin-embedded material, a special set of control gene PCR primers was used resulting in a ladder of four fragments (100, 200, 300 and $400 \mathrm{bp})$ (Suppl. Fig. 1). To evaluate TCR gene rearrangements, T-cell receptor $\gamma$ and $\beta$ chains were investigated using a set of primers $\mathrm{V} \gamma 11-\mathrm{J} \gamma 11, \mathrm{~T} \beta$ D1-T $\beta$ J2 and T $\beta$ D2-T $\beta$ J2 (Suppl. Table 1) (ref. ${ }^{26-28}$ ). For complete IgH gene VH$\mathrm{JH}$ rearrangements, consensus BIOMED-2 sets of primers were used to anneal to the three conserved regions called framework areas (FR1 - FR3) within hypervariable complementarity-determining regions (Suppl. Table 1) (ref., ${ }^{4,15,29,30}$ ). To eliminate false-positive results, heteroduplex analysis was used to analyze the PCR products for discrimination between monoclonal lymphoid cells with identical junctional regions (homoduplexes) and polyclonal lymphoid cells with highly diverse junctional regions (heteroduplexes) (ref. ${ }^{15,31,32}$ ). After heteroduplex analysis, the PCR products were separated in 6\% PAGE gel and visualized with GelRedTM Nucleic Acid Stain (Biotium, USA) on an ultra-violet light illuminator GBox HR-Imaging system (Syngene, UK). The analysis of PCR products on polyacrylamide gels rather than agarose gels is essential to provide sufficient resolution and also enhance detection of dominant bands within background smears (Fig. 2, Suppl. Fig. 3) (ref. ${ }^{33,34}$ ). Further details on the above methods are available in the Supplemental material.

\section{Immunohistochemistry}

Four micrometer sections were cut from formalin-fixed paraffin-embedded tissues and stained with hematoxylineosin, PAS (Periodic Acid Schiff) or used for immunohistochemistry (IHC). Following monoclonal antibodies were used after antigen retrieval by microwave treatment: Bc12 (clone 100; Biogenex), PAX5 (clone 1EW; Leica), CD20 (clone L26; DAKO), CD79a (clone JCB117; DAKO), Ki67 (clone MIB1; DAKO) and polyclonal antibody directed against antigen CD3 (A0452; DAKO). Monoclonal antibody CD21 (clone 1F8; DAKO) was used after antigen retrieval by Proteinase $\mathrm{K}$ digestion. EnVision $^{\mathrm{TM}}+$ Dual Link (DAKO) with diaminobenzidine (Liquid DAB+Substrate Chromogen System, DAKO) was used for visualisation. Staining for CD30 (clone Ber-H2; DAKO) and pan-cytokeratin (clone AE1/AE3; Biogenex) was performed by automated immunostainer Ventana BenchMark (Ventana Medical Systems).

\section{RESULTS}

Of a total of 957 FFPE tissues with no definite diagnosis examined by PCR methods 544 were from B-cells (Table 1) and 413 from T-cells (Table 2). IgH and TCR analyses were carried out simultaneously on 240 samples. Malignant diseases were represented by 437 samples ( 295 from B-cells and 142 from T-cells) while 316 samples were defined as non-neoplastic lesions of a largely inflammatory and reactive type (180 from B-cells and 136 from T-cells). Of the non-neoplastic samples, IgH and TCR clonal bands were visualised in eight $(4.4 \%)$ and three cases $(2.2 \%)$, respectively. A special group consisted of composite lymphomas (4 cases), where clonal rearrangements were confirmed in both B-cells and T-cells. In the case of histiocytic sarcomas, only B-cell clonality was found in one out of five investigated samples.

\section{Analysis of IgH gene clonality in different entities}

B-cell lymphomas were classified according to the WHO classification ${ }^{35}$ into sixteen groups (see Table 1) (ref. ${ }^{35}$ ). Of the total of 295 diagnosed malignant lymphomas, clonal rearrangements were detected in 235 cases (79.7\%). Fourteen malignant cases were not evaluable due to any product after PCR, which represents $95.3 \%$ performance of the assay $(94.7 \%$ when all IgH clonality reactions considered, see Table 1). Of 128 samples simultaneously examined for TCR rearrangement, monoclonal bands were detected in eleven cases (see Table 1 and case reports 6-7). 
Table 1. Results of IgH gene clonality in different entities.

\begin{tabular}{|c|c|c|c|c|c|}
\hline Abbreviation & Entity & $\mathrm{IgH}+$ & IgH- & $\mathrm{n} / \mathrm{a}^{*}$ & Tested \\
\hline B-ALL/LBL & B lymphoblastic leukaemia/lymphoma, NOS & 2 & & 1 & 3 \\
\hline CLL/SLL & $\begin{array}{l}\text { Chronic lymphocytic leukaemia/small lymphocytic } \\
\text { lymphoma }\end{array}$ & 8 & 1 & & 9 \\
\hline LPL & Lymphoplasmacytic lymphoma & 3 & & & 3 \\
\hline SMZL & Splenic B-cell marginal zone lymphoma & 2 & & & 2 \\
\hline NMZL & Nodal marginal zone lymphoma & 4 & & & 4 \\
\hline MALT & Extranodal marginal zone lymphoma & 54 & 2 & 3 & 59 \\
\hline PCL & Plasma cell myeloma/plasmacytoma & 5 & 1 & & 6 \\
\hline FL & Follicular lymphoma & 46 & 6 & 4 & 56 \\
\hline MCL & Mantle cell lymphoma & 4 & & & 4 \\
\hline DLBCL & Diffuse large B-cell lymphoma ${ }^{\#}$ & 51 & 14 & 3 & 68 \\
\hline PBL & Plasmablastic lymphoma & 1 & & & 1 \\
\hline THRLBCL & $\mathrm{T}$ cell/histiocyte-rich large B-cell lymphoma\# & 4 & 4 & & 8 \\
\hline $\mathrm{BL}$ & Burkitt lymphoma & 2 & & & 2 \\
\hline LyG & Lymphomatoid granulomatosis & 1 & & & 1 \\
\hline LB-NS & B-cell lymphoma NS & 35 & 2 & 2 & 39 \\
\hline \multirow[t]{2}{*}{$\mathrm{cHL}$} & Classical Hodgkin lymphoma ${ }^{\#}$ & 13 & 16 & 1 & 30 \\
\hline & & 235 & 46 & 14 & 295 \\
\hline $\mathrm{CL}$ & Composite lymphoma ${ }^{\#}$ & 4 & & & 4 \\
\hline \multirow[t]{4}{*}{ HS } & Histiocytic sarcoma & 1 & 1 & & 2 \\
\hline & T-cell neoplasias & & 61 & 2 & 63 \\
\hline & Non-neoplastic lesion & 8 & 159 & 13 & 180 \\
\hline & & 248 & 267 & 29 & 544 \\
\hline
\end{tabular}

* not available due to no product after PCR

\# several DLBCL, THRLBCL, cHL and composite lymphomas (1, 3, 3 and 4, respectively) were positive for both IgH and TCR rearrangements

Table 2. Results of TCR rearrangements in different entities.

\begin{tabular}{|c|c|c|c|c|c|}
\hline Abbreviation & Entity & TCR+ & TCR- & $\mathrm{n} / \mathrm{a}^{*}$ & Tested \\
\hline T-LBL & T lymphoblastic leukaemia/lymphoma & 2 & & 1 & 3 \\
\hline ANKL & Agressive NK cell leukaemia & & 1 & & 1 \\
\hline ENKTCL & Extranodal NK/T cell lymphoma, nasal type & 3 & 1 & & 4 \\
\hline EATL & Enteropathy-associated T-cell lymphoma & & 1 & & 1 \\
\hline MF & Mycosis fungoides & 13 & 8 & 5 & 26 \\
\hline ALCL ALK+ & Anaplastic large cell lymphoma, ALK positive & 11 & 2 & 1 & 14 \\
\hline ALCL ALK- & Anaplastic large cell lymphoma, ALK negative & 1 & 1 & & 2 \\
\hline PTCLU & Peripheral T-cell lymphoma, unspecified & 46 & 9 & 7 & 62 \\
\hline AITL & Angioimmunoblastic T-cell lymphoma & 3 & 4 & 1 & 8 \\
\hline TL & T lymphoproliferation with no definite diagnosis & 8 & 3 & & 11 \\
\hline LyP & Lymphomatoid papulosis & 1 & 6 & 1 & 8 \\
\hline PCSM-TCL & $\begin{array}{l}\text { Primary cutaneous CD } 4 \text { positive small/medium T-cell } \\
\text { lymphoma }\end{array}$ & 1 & & & 1 \\
\hline \multirow[t]{2}{*}{ T-LGL } & T-cell large granular lymphocytic leukaemia & 1 & & & 1 \\
\hline & & 90 & 36 & 16 & 142 \\
\hline $\mathrm{CL}$ & Composite lymphoma $^{\#}$ & 4 & & & 4 \\
\hline \multirow[t]{4}{*}{ HS } & Histiocytic sarcoma & & 3 & & 3 \\
\hline & B-cell neoplasias & $7^{\mathrm{x}}$ & 118 & 3 & 128 \\
\hline & Non-neoplastic lesion & 3 & 121 & 12 & 136 \\
\hline & & 104 & 278 & 31 & 413 \\
\hline
\end{tabular}

* not available due to no product after PCR

\# composite lymphomas were positive for both IgH and TCR rearrangements

${ }^{\mathrm{x}}$ several DLBCL, THRLBCL, cHL (1, 3 and 3, respectively) were positive for both IgH and TCR rearrangements 


\section{Analysis of TCR rearrangements in different entities}

T-cell lymphomas consisted of thirteen types (see Table 2). In this class, 90 out of 142 cases of malignant lymphoma had a clonal rearrangement (63.4\%). Sixteen malignant cases were not evaluable due to no product after PCR, which represents $88.7 \%$ performance of the assay $(92.5 \%$ when all TCR clonality reactions considered, see Table 2). Except for four cases of B/T composite lymphomas (see case report 6), none of the investigated T-cell lymphomas was positive for IgH clonality.

\section{Histological and molecular studies to resolve problem cases}

The distinction between reactive, atypical and neoplastic lymphoproliferations is sometimes difficult. Each case should be evaluated contextually at the clinical, pathomorphologic and immunophenotypic level (immunohistochemistry and/or immunoflowcytometry) with the powerful contribution of the molecular analysis. We briefly present 10 difficult cases where PCR analysis of IgH and TCR gene rearrangements contributed significantly to a decision on the correct diagnosis (Fig. 1, 2).

\section{Case 1. Lymph node atypical follicular hyperplasia}

A young man (26 years old) experienced enlarged lymph nodes, that revealed dominant cortical hyperplasia with merged non-polarized follicules and a high load of tangible body macrophages, without progressive transformation of germinal centers. Germinal centers showed Bcl-2 negativity and follicular dendritic meshwork (CD21 and CD23 positive) was expanded and altered (Fig. 1a-b). Clonal rearrangement of IgH (VHFR1-3) was detected. Atypical follicular hyperplasia with the detected IgH clonal rearrangement bears higher relative risk of consequent development of non-Hodgkin lymphoma.

\section{Case 2. Lymph node paracortical hyperplasia}

A young man (23 years old) had an enlarged lymph node with dominant paracortical expansion (see PAS staining) including CD3 positive T-cells, histiocytes and interdigitating dendritic cells without formation of epitheloid granulomas (Fig. 1c-d). Secondary lymphoid follicules bear polarization, without any morphologic features of alteration. PCR analysis of TCR genes didn't detect any clonal rearrangement.

\section{Case 3. Lymphomatoid granulomatosis}

A fifty-one year old man with a skin tumour whose histologic evaluation revealed very dense lymphoid infiltration with vascular accentuation and scattered HRS-like cells without tendency to make clusters. None of morphologic features typical for extranodal marginal zone B cell lymphoma (SALT-type) were detected while HRS-like cells bear positivity for CD20, PAX5, CD30 and Ki67 (Fig. 2a-d) and negativity for CD15. IgH clonal rearrangement (VHFR1, VHFR2, VHFR3) was found which confirmed diagnosis of lymphomatoid granulomatosis.
Case 4. Gastric extranodal marginal zone B-cell lymphoma (MALT lymphoma)

A small volume of provided specimen was very limiting for a correct diagnosis for the following case report. Bioptic material from a 53 year old man with expected gastric inflammation revealed dense centrocytoid and monocytoid infiltration with expression of CD20, PAX5 (Fig. 1e-f), CD43 and low Ki-67 positivity (app. 5-10\% of neoplastic cells). CD10, Bcl-6, CD5 and cyclin D1 were negative. An initial follicular colonisation has been disclosed only in one secondary lymphoid follicule from gastric specimen. Detected IgH (VHFR1, VHFR2, VHFR3) clonal rearrangement was crucial for proper determination of diagnosis.

\section{Case 5. Concomitant prostatic adenocarcinoma and MALT lymphoma}

An accompaning lymphoid infiltration is a common "reactive" feature of nearly all invasive epithelial neoplasms, but in the case of very high lymphocytic density a lymphoma should be considered. We revealed CD23 negative and CD20 (Fig. 1g) and PAX5 positive, nearly monomorphic lymphoid infiltration with predominant centrocytoid and monocytoid features, linked to an acinic adenocarcinoma Gleason grade 5 (pan-cytokeratin staining, Fig. 1h) in a surgical specimen of a 68 year old man. The neoplastic lymphoid B-cells showed a splitting type of infiltration and very low Ki-67 index (app. 5\% of neoplastic lymphoid cells). IgH clonal rearrangement (VHFR1, VHFR2, VHFR3) was detected and supported diagnosis of concomitant MALT lymphoma.

\section{Case 6. B/T-cell origin composite lymphoma}

The neoplastic lymphoid infiltration of lung tissue from a 65 year old woman consisted of intermediate and large cells. CD5 (Fig. 1i) expression was detected in the intermediate lymphoid cells (T-cell origin) and large cells showed positivity of CD20 (Fig. 1j), CD30 and MUM1/ IRF4 (characteristics of DLBCL). The clonal rearrangement was detected from the whole specimen both in TCR and $\mathrm{IgH}$ with overall conclusion of $\mathrm{B} / \mathrm{T}$-cell origin composite lymphoma.

\section{Case 7. Diffuse large B-cell lymphoma (DLBCL) with TCR crosslineage infidelity}

Surgery was carried out on a 76 year old man for a large bulky tumor in the small bowel. The neoplastic tissue included mainly immunoblasts with CD20, PAX5 and MUM1/IRF4 positivity and only scattered small CD3, CD5, CD4, CD8 and CD56 positive T-cells (Fig. 1k-1). Proliferative index Ki-67 was more than $80 \%$ in neoplastic B-cell population. The histological features did not match a composite lymphoma. The histological report concluded with immunoblastic non-germinal centre B-celllike subgroup of DLBCL. As both IgH (VHFR1, VHFR2, VHFR3) and TCR $\beta$ (T $\beta$ D1-T $\beta$ J2 and T $\beta$ D2-T $\beta$ J2) clonal rearrangements were detected, the crosslineage infidelity and pseudoclonality were added to the final diagnosis. However, single cell analysis of microdissected cells would be needed for definitive conclusion. 

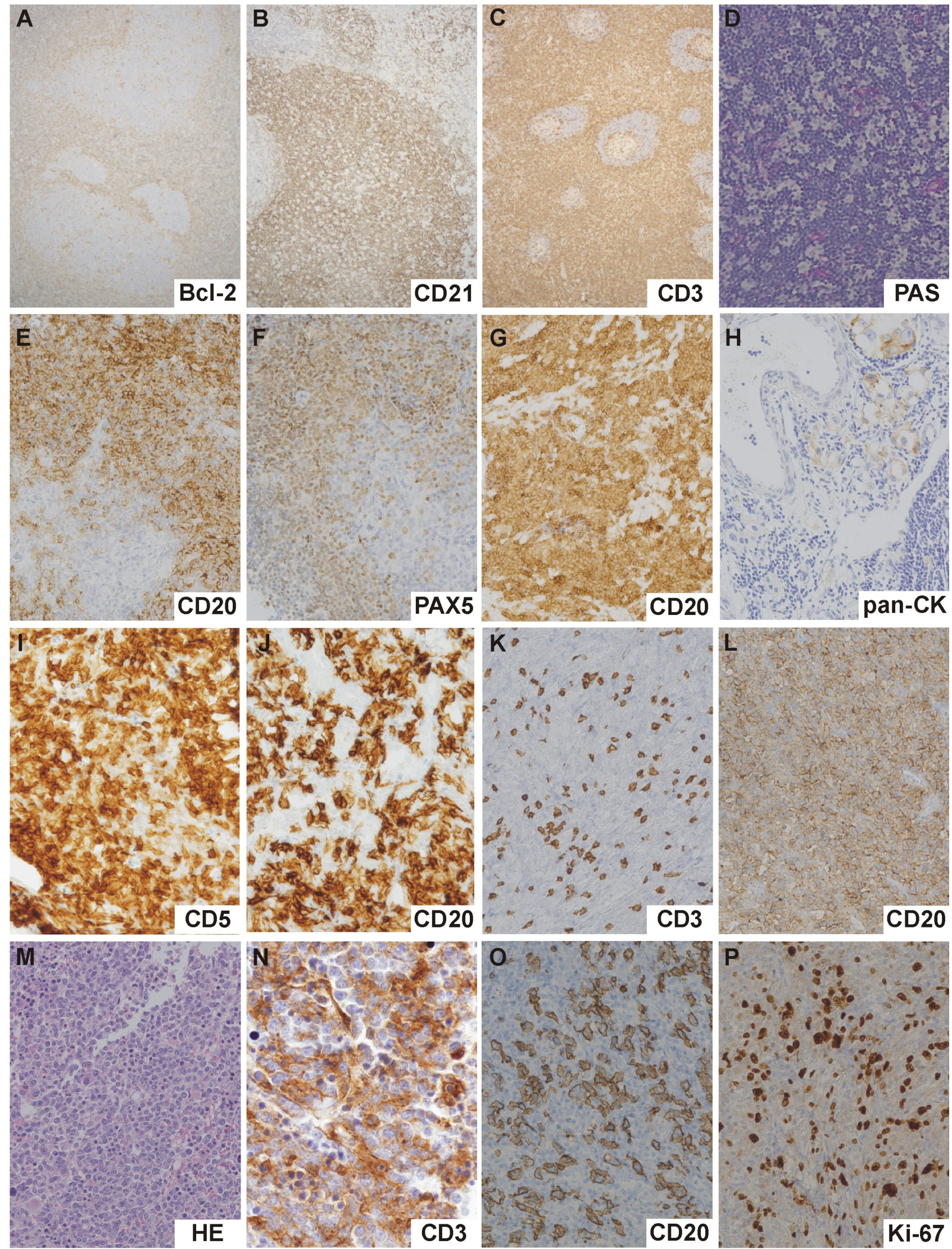

Fig. 1. Morphological and immunohistochemical features of selected cases.

a-b) case 1-lymph node atypical follicular hyperplasia; c-d) case 2 - lymph node paracortical hyperplasia; e-f) case 4 - gastric extranodal marginal zone B-cell lymphoma of MALT-type; g-h) case 5 - concomitant prostatic adenocarcinoma and MALT lymphoma; $\mathrm{i}-\mathrm{j}$ ) case 6 - B/T-cell origin composite lymphoma; $\mathrm{k}-1$ ) case 7 - diffuse large B-cell lymphoma with TCR crosslineage infidelity; m-n) case 8 - agressive NK-cell leukemia; o-p) case 10 - T-cell histiocyte-rich large B-cell lymphoma. HE, hematoxylin and eosin; pan-CK, pan-cytokeratin. Original magnification 40x (a-c), 200x (d-m, o-p) or 400x (n). 

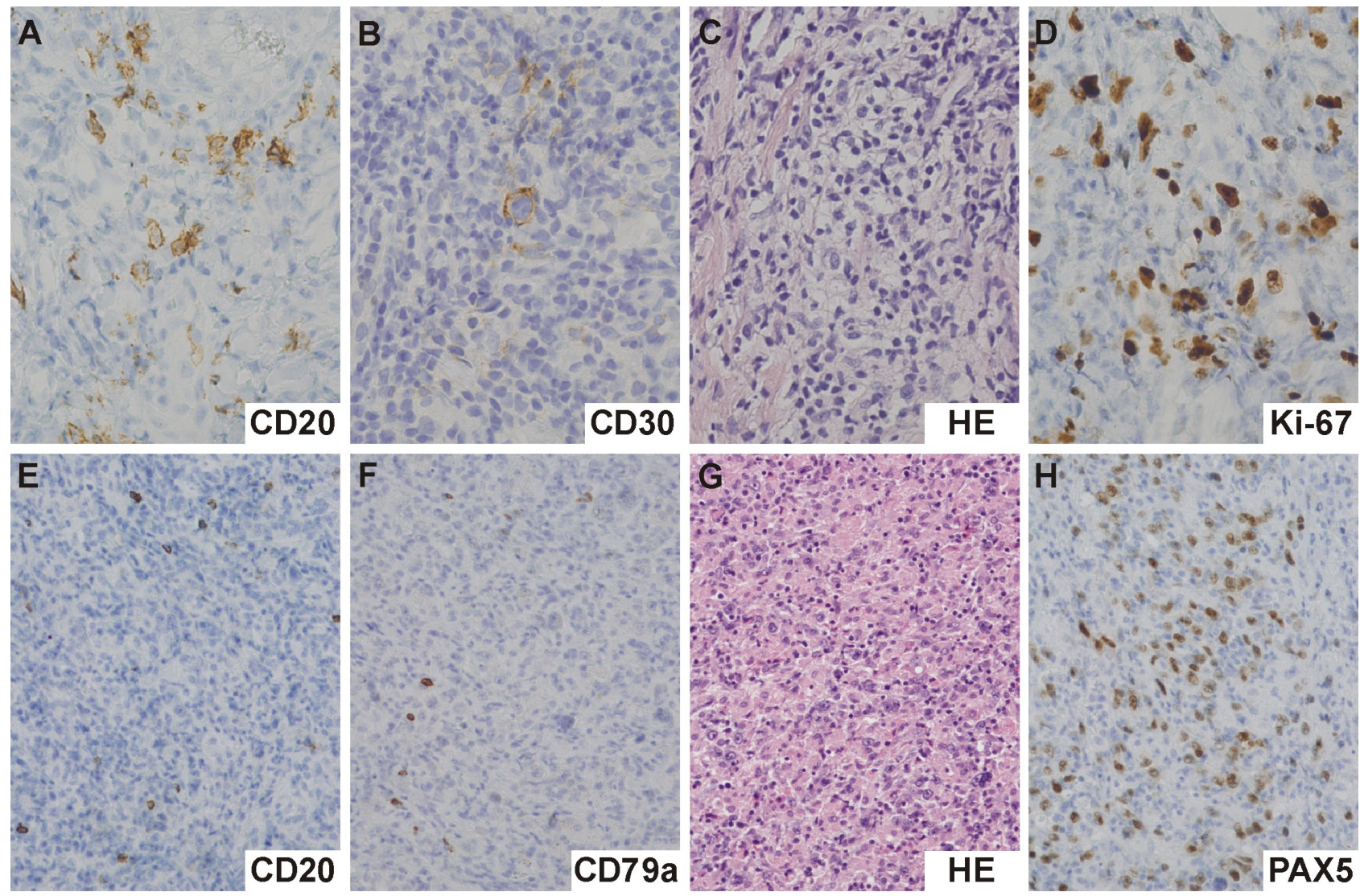

Fig. 2. Morphological and immunohistochemical features of lymphomatoid granulomatosis (a-d; case 3) and CD20/CD79 negative diffuse large B-cell lymphoma (e-h; case 9). HE, hematoxylin and eosin. Original magnification 200x (g) or 400x (a-f, h).

\section{Case 8. Agressive NK-cell leukemia}

A trephine biopsy of a 36 year old man with suspected hematological disease was processed The bone marrow evaluation showed so called "packed marrow" with diffuse infiltration of intermediate and large lymphoid cells only with cytoplasmic CD3 (Fig. 1m-n) and membranous CD56 and negativity of CD5, CD7, CD4, CD8, CD10, CD30, CD57, TIA-1, granzyme B and perforin. TCR $\left(\mathrm{V}_{\gamma} 11-\mathrm{J} \gamma 11, \mathrm{~T} \beta \mathrm{D} 1-\mathrm{T} \beta \mathrm{J} 2\right.$ and $\left.\mathrm{T} \beta \mathrm{D} 2-\mathrm{T} \beta \mathrm{J} 2\right)$ clonal rearrangement was not detected and this result supported germline configuration of TCR genes and agressive NKcell leukemia.

\section{Case 9. CD20 and CD79 negative diffuse large B-cell lymphoma}

Very dense lymphoid infiltration with a fraction of large lymphoid cells was revealed during the histological evaluation of the biopsy of a 69 year old man with a liver tumor. This large lymphoid population was positive only in CD30, MUM1/IRF4 and only in one lineage specific marker PAX5. CD20, CD79a and CD138 were negative and all T-lymphoid markers were negative as well. $\mathrm{Ki}-67$ was positive in more than $90 \%$ of neoplastic cells (Fig. 2e-h). No TCR clonality was found while IgH monoclonal rearrangement confirmed the diagnosis DLBCL.

\section{Case 10. T-cell histiocyte-rich large B-cell lymphoma (THRLBCL)}

A large bulky lung tumor was found in a 72 year old man. The neoplastic tissue encompassed dominant small lymphoid T-cells (CD3 and CD5 positive) with admixed histiocytes (CD68 positive) and only scattered individual large lymphoid cells without tendency to clustering. These large lymphoid cells showed mainly centroblastic features and only small fraction denoted aneu- and polyploid nuclear morphology. Positivity of CD20 as well as Ki-67 (Fig. 1o-p), PAX5 and MUM1/IRF4 was detected in large B-cells. IgH clonal rearrangement was detected and supported diagnosis of T-cell histiocyte-rich large B-cell lymphoma. TCR rearrangement was not detected in this case. Importantly, three other THRLBCL cases were positive also for TCR rearrangement, however, histological and immunohistochemical evaluation excluded the diagnosis of $\mathrm{B} / \mathrm{T}$ composite lymphomas.

\section{DISCUSSION}

The majority of haemato-oncological cases are in the form of FFPE tissues and also all cases delivered to our department for the "second reading" from other hospitals are FFPE tissues. Even though the PCR method is routine in our laboratory, we were concerned that the 
detection of gene rearrangements in lymphomas may be compromised by formalin fixation and processing that can cause DNA fragmentation or degradation (see Suppl. Fig. 1) (ref. $\left.{ }^{8,23,36}\right)$. Of a total of 957 FFPE tissues, only 60 (i.e. 6.3\%) had degraded DNA and therefore the PCR method was not succesful. In cases when the DNA was fragmented and showed amplification of 200 or even only $100 \mathrm{bp}$ for IgH gene targets and $100 \mathrm{bp}$ for TCR gene targets it may not efficiently amplify leading to potentially false-negative results. Hence it is necessary to evaluate the quality, integrity and amplifiability of the DNA extracted from FFPE tissues using a multiple control gene PCR (ref. ${ }^{15,31,36}$ ). Another reason why it is impossible to achieve $100 \%$ success rate in detecting monoclonality of $\mathrm{IgH}$ and TCR genes in lymphomas is the heterogeneity of the targeted DNA sequence. To avoid possible non-homology, more sets of primers should be applied ${ }^{23}$. Furthermore, negative results may be caused by unusual $\mathrm{IgH}$ gene configurations that may arise from partial or incomplete rearrangements ${ }^{6,33}$ and by chromosomal translocations involving the $\mathrm{JH}$ germline gene segment on chromosome 14 (ref. $^{29,37}$ ).

The detection rate of $\mathrm{IgH}$ rearrangement is also closely related to the cell origin of malignant lymphomas ${ }^{9,38,39}$. The most successful detection of amplification by the PCR was achieved for malignant lymphomas derived from pre-germinal center (pre-GC) B-cells which express unmutated variable region genes (e.g. mantle cell lymphoma, MCL). Our results are in concordance with a large study by Hartmann et al. who also reported $100 \%$ detection rate for $\mathrm{MCL}^{39}$. The other groups of tumors derived from memory B-cells generated in the germinal centers and characterized by cells bearing somatically hypermutated variable region genes (GC and post-GC memory B cells) (ref. ${ }^{10,40}$ ) showed a lower rate of clonality by the PCR method due in part to false negatives resulting from improper primer annealing ${ }^{9,15}$. We achieved a lower success rate in the case of follicular lymphomas (FL) and DLBCL ( $88.5 \%$ and $78.5 \%$, respectively) due to both clonally rearranged Ig genes carrying a large number of somatic mutations and intraclonal diversity of germinal center cells ${ }^{41}$. A further obstacle to the successful analysis was the limited number of scattered B-cells in a background of many polyclonal reactive cells masking the monoclonal popula$\operatorname{tion}^{39,42,43}$. However, our detection rate for FL is in good agreement with other studies by Hartmann et al., Berget et al. and McClure et al. ( $83 \%, 80 \%$ and 55\%, respectively) (ref. ${ }^{39,44,45}$ ). The same is true for DLBCL (83\%, 67\% and $63 \%$ in Hartmann et al., McClure et al. and Kosari et al., respectively) (ref. ${ }^{39,45,46}$ ). We detected clonal rearrangements in $96.4 \%$ of MALT lymphomas which is in line with studies by Nikiforova et al., Hartmann et al. and Evans et al. (95\%, 90\% and 84\%, respectively) (ref. ${ }^{3,34,39)}$. The sensitivity for detecting clonality in classical Hodgkin lymphoma (cHL) was the lowest $(45 \%)$ in our study, probably due to the scarcity of tumor cells residing in an abundant admixture of non-malignant cells of different types that produces a polyclonal background signal and due to a high rate of somatic mutations in $\mathrm{V}$ regions ${ }^{1,44-47}$.
Nevertheless, similar detection rates for cHL were also reported by McClure et al., Burack et al. and Hartmann et al. (50\%, 49\% and $32 \%$, respectively) (ref. ${ }^{39,45,50}$ ).

In the group of T-cell lymphomas, the most successful detection of the PCR amplification was achieved for $\mathrm{ALK}^{+}$anaplastic large cell lymphoma (ALCL, 84.6\%) and then for unspecified peripheral T-cell lymphoma (PTCLU, $83.6 \%)$. Our results are somewhat worse than Hartmann et al. (93\% and $88 \%$ for ALCL and PTCLU, respectively) (ref. ${ }^{39}$ ), however, in good concordance with the study of Zaki et al. (50\% and 90\% for ALCL and PTCLU, respectively) (ref. ${ }^{51}$ ). The percentage of detection in the group of mycosis fungoides (MF) was only $62 \%$ and possibly depend upon the number of tumor cells ${ }^{52,53}$. Higher detection rate for MF was reported by Hartmann et al. but the lower one by Gallardo et al. (94\% and 50\%, respectively) (ref. $\left.{ }^{39,54}\right)$. The lowest frequency of clonality $(14.3 \%, 1$ out of 7 samples) was detected in the case of lymphomatoid papulosis (LyP). LyP represents an intriguing cutaneous T-cell proliferation with a benign clinical course but with a histologic appearance reminiscent of malignant lympho$\mathrm{ma}^{55}$. It is known that some clinically benign proliferations have a clonal origin ${ }^{15}$. The failure to detect a dominant clone in many cases does not necessarily reflect the absence of clonal disease and this may be for biological and/ or technical reasons. Hartmann et al. and Gallardo et al. achieved better detection rates for LyP (91\% and 58\%, respectively), probably due to the use of a more sensitive fluorescence-based capillary electrophoresis, as well as higher number of cases analyzed (ref. ${ }^{39,54}$ ).

From the large and various groups of nodal and extranodal lymphoproliferative lesions of mostly inflammatory and reactive changes, 11 clonal rearrangement cases (3.5\%) were found. Extremely high sensitivity of the PCR technique can even detect a small clonal population in the non-neoplastic infiltrates ${ }^{6}$ and therefore pseudoclonality in PCR-based clonality studies is difficult to interpret in cases of benign proliferation ${ }^{6,15}$. Another serious problem is a false-positive result, therefore heteroduplex analysis is used to discriminate between monoclonal, oligoclonal and polyclonal PCR products ${ }^{15,34,56}$. Nearly $8 \%$ of cases of non-neoplastic lesions were damaged due to tissue formalin fixation which resulted in fragmented DNA and subsequent unsuccessful PCR analysis ${ }^{10,57}$. For this reason, testing the quality of the extracted DNA in pathological specimens is important, particularly when using FFPE tissues $^{2,31}$.

\section{CONCLUSION}

The results of this study corfirm that PCR amplification of $\mathrm{IgH}$ and TCR rearrangement genes is a reliable method for detection of B- and T-cell clonality from FFPE tissue. In particular, molecular methods significantly improve the ability of pathologists to more accurately determine the correct diagnosis of lymphoid neoplasia in specimens in which histological and immunophenotypic studies are inconclusive. 
Acknowledgement: We thank Alena Lukasova, Eva Pimrova and Jana Holinkova for their excellent technical assistance. This work was supported in part by grants NT11103 and DRO (FNOL, 98892) from the Czech Ministry of Health, NPS I LO1304, DRO (UP, 61989592) from the Czech Ministry of Education and LF_2017_021 from Palacky University.

Author contributions: MS perfomed PCR analysis, collected data and wrote the manuscript;, MT, PF, ZK interpreted the pathological diagnosis; PF also interpreted immunohistochemical analysis, JS, JB contributed to PCR analysis and wrote the manuscript.

Conflict of interest statement: The authors state that there are no conflicts of interest regarding the publication of this article.

\section{REFERENCES}

1. Medeiros LJ, Carr J. Overview of the role of molecular methods in the diagnosis of malignant lymphomas. Arch Pathol Lab Med 1999;123:1189-207.

2. Langerak AW, Groenen PJ, Jm van Krieken JH, van Dongen JJ. Immunoglobulin/T-cell receptor clonality diagnostics. Expert Opin Med Diagn 2007;1:451-61.

3. Evans PA, Pott Ch, Groenen PJ, Salles G, Davi F, Berger F, Garcia JF, van Krieken JH, Pals S, Kluin P, Schuuring E, Spaargaren M, Boone E, Gonzalez D, Martinez B, Villuendas R, Gameiro P, Diss TC, Mills K, Morgan GJ, Carter GI, Milner BJ, Pearson D, Hummel M, Jung W, Ott M, Canioni D, Beldjord K, Bastard C, Delfau-Larue MH, van Dongen Jנ J, Molina TJ, Cabecadas J. Significantly improved PCR-based clonality testing in B-cell malignancies by use of multiple immunoglobulin gene targets. Report of the BIOMED-2 Concerted Action BHM4CT98-3936. Leukemia 2007;21:207-14.

4. Ramasamy I, Brisco M, Morley A. Improved PCR method for detecting monoclonal immunoglobulin heavy chain rearrangement in $B$ cell neoplasms. J Clin Pathol 1992;45:770-5.

5. Elenitoba-Johnson KS, Bohling SD, Mitchell RS, Brown MS, Robetorye RS. PCR analysis of the immunoglobulin heavy chain gene in polyclonal processes can yield pseudoclonal bands as an artifact of low B cell number. J Mol Diagn 2000;2:92-6.

6. Tai YC, Peh SC. Feasibility of T-cell receptor gamma (TCRgamma) gene angement on formalin-fixed, paraffin-embedded tissues by PCR assays. Singapore Med J 2003;44:250-5.

7. Bielawski K, Zaczek A, Lisowska U, Dybikowska A, Kowalska A, Falkiewicz B. The suitability of DNA extracted from formalin-fixed paraffin-embedded tissues for double differential polymerase chain reaction analysis. Int J Mol Med 2001;8:573-8.

8. Srinivasan M, Sedmak D, Jewell S. Effect of fixatives and tissue processing on the content and integrity of nucleic acids. Am J Pathol 2002;161:1961-71.

9. Theriault C, Galoin S, Valmary S, Selves J, Lamant L, Roda D, Rigal-Huguet F, Brousset P, Delsol G, Al Saati T. PCR analysis of immunoglobulin heavy chain $(\mathrm{lgH})$ and TcR-gamma chain gene rearrangements in the diagnosis of lymphoproliferative disorders: results of a study of 525 cases. Mod Pathol 2000;13:1269-79.

10. Gurbity TP, Bagdi E, Groen NA, Budel LM, Abbou M, Krenacs L, Dinjens WN. Increased sensitivity of B-cell clonality analysis in formalin-fixed and paraffin-embedded B-cell lymphoma samples using an enzyme blend with both 5'-->3' DNA polymerase and 3'-->5' exonuclease activity. Virchows Arch 2003;443:643-8.

11. Tonegawa S. Somatic generation of antibody diversity. Nature 1983;302:575-81.

12. Trainor KJ, Brisco MJ, Story CJ, Morley AA. Monoclonality in B-lymphoproliferative disorders detected at the DNA level. Blood 1990;75:2220-2.

13. Corneo B, Moshous D, Gungor T, Wulffraat N, Philippet P, Le Deist FL, Fischer A, de Villartay JP. Identical mutations in RAG1 or RAG2 genes leading to defective $V(D) J$ recombinase activity can cause either T-B- severe combined immune deficiency or Omenn syndrome. Blood 2001;97:2772-6.

14. Bassing $\mathrm{CH}$, Swat W, Alt FW. The mechanism and regulation of chromosomal V(D)J recombination. Cell 2002;109 Suppl:S45-55.

15. van Dongen JJ, Langerak AW, Bruggemann M, Evans PA, Hummel M, Lavender FL, Delabesse E, Davi F, Schuuring E, Garcia-Sanz R, van Krieken JH, Droese J, Gonzalez D, Bastard C, White HE, Spaargaren M, Gonzalez M, Parreira A, Smith JL, Morgan GJ, Kneba M, Macintyre EA. Design and standardization of PCR primers and protocols for detection of clonal immunoglobulin and T-cell receptor gene recombinations in suspect lymphoproliferations: report of the BIOMED-2 Concerted Action BMH4-CT98-3936. Leukemia 2003;17:2257-317.

16. Vanasse GJ, Concannon P, Willerford DM. Regulated genomic instability and neoplasia in the lymphoid lineage. Blood 1999;94:39974010.

17. Messier TL, O'Neill JP, Hou SM, Nicklas JA, Finette BA. In vivo transposition mediated by $\mathrm{V}(\mathrm{D}) \mathrm{J}$ recombinase in human $\mathrm{T}$ lymphocytes. EMBO J 2003;22:1381-8.

18. Inlay $M, X u$ Y. Epigenetic regulation of antigen receptor rearrangement. Clin Immunol 2003;109:29-36.

19. Boule JB, Rougeon F, Papanicolaou C. Terminal deoxynucleotidyl transferase indiscriminately incorporates ribonucleotides and deoxyribonucleotides. J Biol Chem 2001;276:31388-93.

20. Bagg A. Immunoglobulin and T-cell receptor gene rearrangements: minding your B's and T's in assessing lineage and clonality in neoplastic lymphoproliferative disorders. J Mol Diagn 2006;8:426-9quiz526-7.

21. Lorenzen J, Jux G, Zhao-Hohn M, Klockner A, Fischer R, Hansmann ML. Detection of T-cell clonality in paraffin-embedded tissues. Diagn Mol Pathol 1994;3:93-9.

22. Benhattar J, Delacretaz F, Martin P, Chaubert P, Costa J. Improved polymerase chain reaction detection of clonal T-cell lymphoid neoplasms. Diagn Mol Pathol 1995;4:108-12.

23. Kusic B, Dominis M, Dzebro S, Antica M. Molecular insight into the diagnosis of lymphoma. Int J Mol Med 2003;12:667-71.

24. Bagg A, Braziel RM, Arber DA, Bijwaard KE, Chu AY. Immunoglobulin heavy chain gene analysis in lymphomas: a multi-center study demonstrating the heterogeneity of performance of polymerase chain reaction assays. J Mol Diagn 2002;4:81-9.

25. Svachova M, Tichy M. PCR analysis of immunoglobulin heavy chain and TCR gene rearrangements in diagnosis of lymphoproliferative disorders on formalin-fixed, paraffin-embedded tissues. Neoplasma 2008;55:36-41.

26. Mitha N, McGlennen RC. Methods to detect clonal gene rearrangements in lymphomas and leukemias. Methods Mol Med 2001;49:189-209.

27. McCarthy KP, Sloane JP, Kabarowski JH, Matutes E, Wiedemann LM. A simplified method of detection of clonal rearrangements of the T-cell receptor-gamma chain gene. Diagn Mol Pathol 1992;1:173-9.

28. McCarthy KP, Sloane JP, Kabarowski JH, Matutes E, Wiedemann LM. The rapid detection of clonal T-cell proliferations in patients with lymphoid disorders. Am J Pathol 1991;138:821-8.

29. Gleissner B, Maurer J, Thiel E. Detection of immunoglobulin heavy chain genes rearrangements in B-cell leukemias, lymphomas, multiple myelomas, monoclonal and polyclonal gammopathies. Leuk Lymphoma 2000;39:151-5.

30. Nihal M, Mikkola D, Wood GS. Detection of clonally restricted immunoglobulin heavy chain gene rearrangements in normal and lesional skin: analysis of the B cell component of the skin-associated lymphoid tissue and implications for the molecular diagnosis of cutaneous B cell lymphomas J Mol Diagn 2000;2:5-10.

31. Groenen PJ, Langerak AW, van Dongen JJ, van Krieken JH. Pitfalls in TCR gene clonality testing: teaching cases. J Hematop 2008;1:97109.

32. Gonzalez M, Gonzalez D, Lopez-Perez R, Garcia-Sanz R, Chillon MC, Balanzategui A, Mateos MV, Alaejos I, Langerak AW, Orfao A, Van Dongen JJ, San Miguel JF. Heteroduplex analysis of VDJ amplified segments from rearranged $\mathrm{IgH}$ genes for clonality assessments in B-cell non-Hodgkin's lymphoma. A comparison between different strategies. Haematologica 1999;84:779-84.

33. Diss TC, Pan L, Peng H, Wotherspoon AC, Isaacson PG. Sources of DNA for detecting B cell monoclonality using PCR. J Clin Pathol 1994;47:493-6.

34. Nikiforova MN, Hsi ED, Braziel RM, Gulley ML, Leonard DG, Nowak 
JA, Tubbs RR, Vance GH, Van Deerlin VM. Detection of clonal IGH gene rearrangements: summary of molecular oncology surveys of the College of American Pathologists. Arch Pathol Lab Med 2007:131:185-9.

35. Campo E, Swerdlow SH, Harris NL, Pileri S, Stein H, Jaffe ES. The 2008 WHO classification of lymphoid neoplasms and beyond: evolving concepts and practical applications. Blood 2011;117:5019-32.

36. Miettinen M, Lasota J. Polymerase chain reaction based gene rearrangement studies in the diagnosis of follicular lymphoma--performance in formaldehyde-fixed tissue and application in clinical problem cases. Pathol Res Pract 1997;193:9-19.

37. Langerak AW, Groenen PJ, Bruggemann M, Beldjord K, Bellan C, Bonello L, Boone E, Carter Gl, Catherwood M, Davi F, Delfau-Larue MH, Diss T, Evans PA, Gameiro P, Garcia Sanz R, Gonzalez D, Grand D, Hakansson A, Hummel M, Liu H, Lombardia L, Macintyre EA, Milner BJ, Montes-Moreno S, Schuuring E, Spaargaren M, Hodges E, van Dongen JJ. EuroClonality/BIOMED-2 guidelines for interpretation and reporting of $\mathrm{Ig} / \mathrm{TCR}$ clonality testing in suspected lymphoproliferations. Leukemia 2012;26:2159-71.

38. Segal GH, Jorgensen T, Scott M, Braylan RC. Optimal primer selection for clonality assessment by polymerase chain reaction analysis: II. Follicular lymphomas. Hum Pathol 1994;25:1276-82.

39. Hartmann $S$, Helling $A$, Döring $C$, Renné $C h$. Clonality testing of malignant lymphomas with the BIOMED-2 primers in a large cohort of 1969 primary and consultant biopsies. Pathology - Research and Practice 2013;209:495-502

40. Kuppers R, Klein U, Hansmann ML, Rajewsky K. Cellular origin of human B-cell lymphomas. N Engl J Med 1999;341:1520-9.

41. Brauninger A, Kuppers R, Spieker T, Siebert R, Strickler JG, Schlegelberger B, Rajewsky K, Hansmann ML. Molecular analysis of single B cells from T-cell-rich B-cell lymphoma shows the derivation of the tumor cells from mutating germinal center B cells and exemplifies means by which immunoglobulin genes are modified in germinal center B cells. Blood 1999;93:2679-87.

42. Child FJ, Woolford AJ, Calonje E, Russell-Jones R, Whittaker SJ. Molecular analysis of the immunoglobulin heavy chain gene in the diagnosis of primary cutaneous B cell lymphoma. J Invest Dermatol 2001;117:984-9.

43. Venkatraman L, Catherwood MA, Patterson A, Lioe TF, McCluggage WG, Anderson NH. Role of polymerase chain reaction and immunocytochemistry in the cytological assessment of lymphoid proliferations. J Clin Pathol 2006;59:1160-5.

44. Berget $E$, Helgeland L, Molven A, Vintermir OK. Detection of clonality in follicular lymphoma using formalin-fixed, paraffin embedded tissue samples and BIOMED-2 immunoglobulin primers. J Clin Pathol 2011;64:37-41.

45. McClure RF, Kaur P, Pagel E, Ouillette PD, Holtegaard CE, Treptow $\mathrm{CL}$, Kurtin PJ. Validation of immunoglobulin gene rearrangement detection by PCR using commercially available BIOMED-2 primers. Leukemia 2006;20:176-9.

46. Kosari F, Shishehbor F, Saffar H, Sadeghipour A. PCR-based clonality analysis in diffuse large B-cell lymphoma using BIOMED-2 primers of $\operatorname{lgH}(F R 3)$ on formalin-fixed paraffin embedded tissue. Arch Iran Med 2013;16:526-9.

47. Kanzler H, Kuppers R, Hansmann ML, Rajewsky K. Hodgkin and ReedSternberg cells in Hodgkin's disease represent the outgrowth of a dominant tumor clone derived from (crippled) germinal center B cells. J Exp Med 1996;184:1495-505.

48. Seitz V, Hummel M, Marafioti T, Anagnostopoulos I, Assaf C, Stein H. Detection of clonal T-cell receptor gamma-chain gene rearrangements in Reed-Sternberg cells of classic Hodgkin disease. Blood 2000;95:3020-4.

49. Hebeda KM, Van Altena MC, Rombout P, Van Krieken JH, Groenen PJ. PCR clonality detection in Hodgkin lymphoma. J Hematop 2009;2:34-41.

50. Burack WR, Laughlin TS, Friedberg JW, Spence JM, Rothberg PG PCR assays detect B-lymphocyte clonality in formalin-fixed, paraffin-embedded specimens of classical hodgkin lymphoma without microdissection. Am J Clin Pathol 2010;134:104-11.

51. Zaki MA, Wada N, Kohara M, Ikeda J, Hori Y, Fujita S, Ogawa $H_{\text {, }}$ Sugiyama H, Hino M, Kanakura Y, Morii E, Aozasa K. Presence of B-cell clones in T-cell lymphoma. Eur J Haematol 2011;86:412-9.

52. Whittaker SJ, Smith NP, Jones RR, Luzzatto L. Analysis of beta, gam$\mathrm{ma}$, and delta T-cell receptor genes in mycosis fungoides and Sezary syndrome. Cancer 1991;68:1572-82.

53. Ponti R, Quaglino P, Novelli M, Fierro MT, Comessatti A, Peroni A, Bonello $L$, Bernengo MG. T-cell receptor gamma gene rearrangement by multiplex polymerase chain reaction/heteroduplex analysis in patients with cutaneous T-cell lymphoma (mycosis fungoides/ Sezary syndrome) and benign inflammatory disease: correlation with clinical, histological a Br J Dermatol 2005;153:565-73.

54. Gallardo F, Costa C, Bellosillo B, Solé F, Estrach T, Servitje O, GarcíaMuret MP, Barranco C, Serrano S, Pujol RM. Lymphomatoid Papulosis Associated with Mycosis Fungoides: Clinicopathological and Molecular Studies of 12 Cases. Acta Derm Venereol 2004;84:463-8.

55. Steinhoff M, Hummel M, Anagnostopoulos I, Kaudewitz P, Seitz V Assaf C, Sander C, Stein H. Single-cell analysis of CD30+ cells in lymphomatoid papulosis demonstrates a common clonal T-cell origin. Blood 2002;100:578-84

56. Langerak AW, Szczepanski T, van der Burg M, Wolvers-Tettero IL, van Dongen JJ. Heteroduplex PCR analysis of rearranged T cell receptor genes for clonality assessment in suspect $\mathrm{T}$ cell proliferations. Leukemia 1997;11:2192-9.

57. Zhou XG, Sandvej K, Gregersen N, Hamilton-Dutoit SJ. Detection of clonal B cells in microdissected reactive lymphoproliferations: possible diagnostic pitfalls in PCR analysis of immunoglobulin heavy chain gene rearrangement. Mol Pathol 1999;52:104-10.

\section{Supplemental Material:}

The online version of this article (doi: 10.5507/

bp.2017.006) offers supplemental material. 